\title{
Examination of the Character Value of "Padusan Tradition" in Pengging Banyudono District, Boyolali Regency
}

\author{
Suyahman
}

\begin{abstract}
This study aims to describe the character values contained in the "tradition of padusan" in the Pengging bath in Banyudono Subdistrict, Boyolali Regency. This research includes qualitative research with a descriptive approach. The subjects of this study were the perpetrators of "traditional padusan" and street vendors around the Pengging bathing area, the object of the research was; character value and 'padusan tradition'. Data collection methods: observation, interviews and documentation. To find out the validity of the data, data triangulation and methods are used. Data analysis techniques using interactive analysis techniques consisting of 3 stages: data reduction, data display and data verification. The results of the study: based on the observations in the field that researchers did since May 2018 found the following: the padusan tradition is carried out every year, the implementation of padusan tradition 2 days before the fasting month, the padusan starting from children to adults, there is entertainment dangdut music with famous singers, ticket prices rose 100\%, many traders around the padusan area in Pengging baths, parking of motorbikes and cars doubled with parking wages increasing by 50\%, crowded atmosphere of padusan, discipline in the padusan participants dress modestly and neatly, the padusan participants cannot bring and consume, drugs, alcohol, the participants can choose the available swimming pool there are 4 swimming pool choices, and the padusan participants cannot do rituals. The results of interviews with the Padusan tradition actors were found as follows; the reason for joining the padusan is simply to follow in the footsteps of his friends, siblings and family, the purpose of following padusan to be clean and to practice fasting, follow the padusan looking for entertainment, following the padusan filling his spare time, following the padusan preserving the value of local wisdom, following the preservation customs. Interviews with the expert interpreters and street vendors obtained information that the "Padusan Tradition": bring income, padusan tradition fosters awareness, help help and work together with others, the padusan tradition encourages closeness to God Almighty. The conclusion: that the "padusan tradition" contains many character values including; religious, discipline, mutual cooperation, help.
\end{abstract}

Index Terms: Character value and "Padusan Tradition".

\section{INTRODUCTION}

Welcoming the Holy Month of Ramadan, Muslims in the archipelago have a variety of ways and traditions. Especially for Javanese people on various recitation opportunities in the month of Rajab. The kiai, ulama and ustadz have warned with the will that Rajab is the month of Allah. Ruwah or Sya'ban is the month of the Prophet.(Maryanto, 2017)

Ramadan is the month of the Islamic ummah. So the tradition teaches that starting in the month of Rajab, the Islamic ummah must have prepared to prepare for the coming of the moon which has a night that exceeds the glory of a thousand months. Because Ramadan is a holy month and a very special month. In the month of Rajab commemorated the events of Isra 'Mi'raj, in the month of Ruwah Muslims practice the teachings of lust or even glorify and worship parents. Wabil specifically told the spirit of deceased parents. So as a gateway to start a series of Ramadan services, humans must purify themselves, both physically and spiritually. This is why the tradition of 'PADUSAN' is present in the community.(Martadiastuti, Harijoko, Warmada, \& Yonezu, 2018)

By sending a prayer and asking forgiveness in a series of sadranan or nyadran events. This Sadranan is one of the values of local wisdom. By doing sadranan it can foster inner consciousness because it has prayed for its ancestors. This is so that in time for the Holy Month of Ramadhan to arrive, the ummah of Islam are ready to be born physically and mentally to maximize the practice of worship and achieve virtues and triumphs in fighting all temptations. Padusan, from the word adus in Javanese, means "bathing" gets the prefix pa and the ending which means bathing. Padusan in this case means the process of bathing activity. In terms of culture, padusan is a tradition of people to clean themselves or take a big bath with the intention of purifying the body and soul in order to welcome the arrival of special days or months.

The Padusan ritual is one form of local wisdom values that has religious nuances. The Padusan ritual is also a culture of Javanese acculturation and Islam which aims to purify oneself into the month of Ramadan the next day.

This research focused on analyzing the character values of the Padusan tradition. The main problem is formulated first: what character values are there in the padusan tradition? Second, what is the impact of the economic value of the implementation of the padusan tradition in the pengging bath in the Banyudono sub-district, Boyolali Regency? 


\section{THEORITICAL REVIEW}

Padusan tradition every month before the month of Ramadan the meaning continues to shift following the times. No longer to cleanse themselves, namely rokhani and physical, but also become entertainment and tourism that is cheap.

The heritage of the Wali Songo heritage was originally believed to be a tradition for cleansing oneself physically and spiritually, before performing fasting in the month of Ramadan. In the past, this tradition was carried out by visiting springs that people believed or believed could bring blessings. Residents of a large bath in that place, by cleaning the body from head to toe It is said that in Yogyakarta the tradition of Padusan has existed since the reign of Sri Sultan Hamengku Buwono I. This tradition was routinely carried out on H-1 Ramadhan or the day before the fasting month in mosque pools and springs determined by the palace. Usually only men do the padusan by throwing themselves into the pool. Continuing with playing water together in that place. Whereas adult women do not do padusan with men in the same pond. Entering the 1950s the tradition of padusan in the palace mosque pool and source of water began to be abandoned by the community. In its development, padusan is interpreted as physical cleansing and rokhani, which can be done anywhere, and can be done alone.

After the 1970s this tradition still continued to be of interest to the people, even the trend was carried out together, men and women mixed in the same place, namely public baths and rivers. Padusan has become a lively entertainment and tour.

But over time, many shifts in the concept and ritual of padusan from just cleaning activities became a kind of cultural event, so we can see this padusan activity carried out accompanied by various entertainment such as campursari music and "dangdutan".

On the other hand, men and women who are already acutely baligh take a bath together in a pond or river, by opening each other's genitals, so that the purpose of cleaning activities is to become an eye wash.(Andina, Ridwan, \& Rahmawati, 2019)

The model of activity that shifts in this direction clearly does not enter into a strict Islamic culture in regulating the interaction between men and women who are not their followers. Let alone see genitals, or the shape of a woman's body that forms due to wet clothing. An adult woman showing her hair in front of a man who is not just her husband is forbidden.

Moreover, in discussing the jurisprudence of worship, bathing before the entry of Ramadhan does not include forms of worship such as the circumcision bath when it will enter the 1st Shawwal (Eid) or when it will enter the 10th Dulhijah (Eid al-Adha). So bathing before entering the month of Ramadan is a normal bath, as well as taking a shower every day to cleanse the body.(Widhiyastuti, Daerobi, \& Samudro, 2018)

Bathing the model is natural, which is done as long as it does not exceed the things that are forbidden such as opening aurat in public. Maybe it's good to be innocent and straighten out perceptions about the solids like the philosophies that the guardians want first, so that the padusan remains included in the integral part of the Islamic culture, it would be very good if the padusan was done individually in a closed place, if indeed the goal is to improve quality and personal hygiene, so that worship feels more comfortable in the month of Ramadan. The essence of "Padusan" for Javanese society is a tradition of purification of the body before Muslims fast. "Padusan" is done by bathing with adults, teenagers and children in a special place with the aim of cleansing the body. Traditions carried out in the morning until the evening before the nightfall (the first tarawih night) are usually carried out in a crowd by Muslims both in the source, spring, river, and clear water flowing river (Rubai: 2018: 28)(Andina et al., 2019)

After doing "padusan", Muslims will feel unanimous determination to do fasting for a month. This fact shows that "padusan" is the key to opening the gate before entering fasting which cannot be separated from obstacles and temptations. The village of Mawa is the way the country is governed. Thus the Javanese proverb implies that every village and country has different procedures. Therefore what was described above just illustrates the implementation of Javanese traditions before the coming of Ramadan. A typical tradition of Muslims in the life sphere of Javanese people who still care about their ancestral culture, even though the tradition is merely interpreted as a symbol and does not reflect the practice of their fellowship with shaytan. However, this issue does not need to be contested. Let the tradition take place by flowing in time and time.

According to Budi (2018) from the economical aspect the implementation of the Padusan tradition is very beneficial both for the people around the Padusan neighborhood and for the local government. Another thing according to Soni, a teenager who lives in the neighborhood around the Padusan tradition area with the presence of bringing in parking lots so as to provide activities for teenagers and at the same time provide financial input for their youth organizations. Unlike Fery (2019) the Padusan tradition has a lot of economic value for residents who live around the location of Padusan can sell drinks and drinks, for hawkers can sell ice tea ice orange and snacks, for youth youth can sell parking services, and for local hansip can sell services for traffic management, after the wonogiri district government can get an in come, for tourism services the tradition of padusan is a means of promotion. Furthermore, according to Kukuh (2018), it was confirmed that a large bath or padusan in padusan procession did not have anything to do with fasting, why? Because fasting is holding back eating, drinking, and everything that cancels fasting from sunrise to sunset, by observing the pillars and the conditions for fasting. The large bath which is more closely related to the work is prayer worship, because the person who performs the prayer must be holy from large and small quantities. Clean large and small areas, among others, by cleaning themselves through

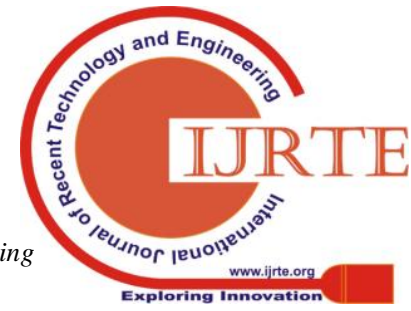


bathing.

\section{METHOD}

This research is a type of qualitative research. Bogdan and Taylor define "qualitative methodology" as a research procedure that produces descriptive data in the form of written or oral words from people and observable behavior. Whereas kirk and miller define that qualitative research is a certain tradition in social knowledge that is fundamentally dependent on observations in humans in their own region and in relation to these people in their discussion and in their terminology. The approach used in this study is an explorative approach which is to explore the character values that exist in the Padusan tradition.

The subject of the research was the visitors of the Padusan tradition, residents in the vicinity of the Padusan tradition in Pengging Baths, Banyudono Subdistrict, Boyolali Regency, and the object was a study of tradition in terms of religious and economic aspects. Data collection methods used are: observation, interviews and documentation. Data validity is done by means of data triangulation and methods.

Data analysis techniques are carried out by qualitative analysis techniques. According to Miles and Huberman, there are three qualitative data analysis techniques, namely data reduction, data presentation and conclusion drawing. This process continues throughout the research, even before the data is actually collected. 1. Data Reduction Data reduction is one of the qualitative data analysis techniques. Data reduction is a form of analysis that sharpens, classifies, directs, removes unnecessary and organizes data so that final conclusions can be taken. Reduction does not need to be interpreted as quantification of data. 2. Data presentation is one of the qualitative data analysis techniques. Presentation of data is an activity when a set of information is compiled, thus giving a possibility of conclusions. The form of presentation of qualitative data is in the form of narrative texts (in the form of field notes), matrices, graphs, networks and charts. 3. Withdrawal of Conclusions Draw conclusions is one of the qualitative data analysis techniques. Drawing conclusions is the result of analysis that can be used to take action.

\section{RESEARCH RESULTS AND DISCUSSION}

\section{A. Research Results}

Based on observations made during the first month of May 2018, character values found in the "Padusan tradition" are: religious character values, cooperative character values, character values help, values of democratic character, and values of caring character. Explanation of these character values as below:

1. Value This religious character is shown by the ritual prayer of salvation one day before the tradition of padusan begins, a prayer so that the visitors and residents who join the padusan are kept away from danger. As well as a one-day prayer ritual after the Padusan tradition is completed as a thank you to the widhi who mastered the universe who has provided safety and fluency in the implementation of the Padusan tradition.

2. The value of the Character of cooperation, shown by the awareness of the local residents working together to eliminate the area around the tradition of padusan, clean the environment around the padusan and clean the pond for padusan. In addition, there are volunteers who prepare free snacks and drinks for mutual cooperation. For the youth there are also busy giving signs / directions to the direction of the Padusan tradition

3. Character values please help shown by the sellers of street vendors when preparing open stalls they help each other to make open stalls. Likewise, the teenagers who will prepare their parking location also help to lend their tools to make the parking location safe, comfortable,

4. The value of democratic character is indicated by an agreement with the parking lot clerks who cannot take the motorbike and car parkers and the price of the parking has been agreed upon so that it does not damage a caravan. For the traders of Buk a Lapak, they have also made a joint agreement about the price of goods sold that are not allowed to run out of fishing rods and may not win over buyers.

5. Value Caring character is shown by responsiveness if there are visitors who ask questions or there are visitors who lose something and there are visitors who want to cross the road and there are visitors who suddenly get sick

Based on the results of interviews with visitors of the "Padusan tradition", the street vendors, street vendors and parking service sellers obtained the following information:

\begin{tabular}{|c|c|c|c|c|c|}
\hline \multirow[b]{2}{*}{$\begin{array}{l}\mathbf{N} \\
\mathbf{0}\end{array}$} & \multirow[b]{2}{*}{ Questions } & \multicolumn{4}{|c|}{ Answers } \\
\hline & & $\begin{array}{l}\text { to } \\
\text { Pedestria } \\
\text { n } \\
\text { Visitors } \\
\end{array}$ & $\begin{array}{l}\text { Street } \\
\text { vendors }\end{array}$ & hawkers & $\begin{array}{l}\text { parking } \\
\text { officers }\end{array}$ \\
\hline 1 & $\begin{array}{l}\text { Do you } \\
\text { know } \\
\text { about the } \\
\text { tradition of } \\
\text { Padus }\end{array}$ & $\begin{array}{l}\text { Of the } 30 \\
\text { visitors } \\
28 \\
\text { answered } \\
\text { yes and } 2 \\
\text { visitors } \\
\text { answered } \\
\text { they did } \\
\text { not know }\end{array}$ & $\begin{array}{l}\text { From } 20 \\
\text { street } \\
\text { vendors } \\
19 \\
\text { answered } \\
\text { yes and } 1 \\
\text { street } \\
\text { vendor } \\
\text { said they } \\
\text { did not } \\
\text { know }\end{array}$ & $\begin{array}{l}\text { Of the } 20 \\
\text { hawkers } \\
18 \\
\text { answered } \\
\text { yes and } 2 \\
\text { hawkers } \\
\text { said they } \\
\text { did not } \\
\text { know }\end{array}$ & $\begin{array}{l}\text { Of the } 20 \\
\text { parking } \\
\text { service } \\
\text { sellers } 19 \\
\text { answered } \\
\text { yes and } 1 \\
\text { parking } \\
\text { service } \\
\text { seller } \\
\text { answered } \\
\text { no idea }\end{array}$ \\
\hline
\end{tabular}




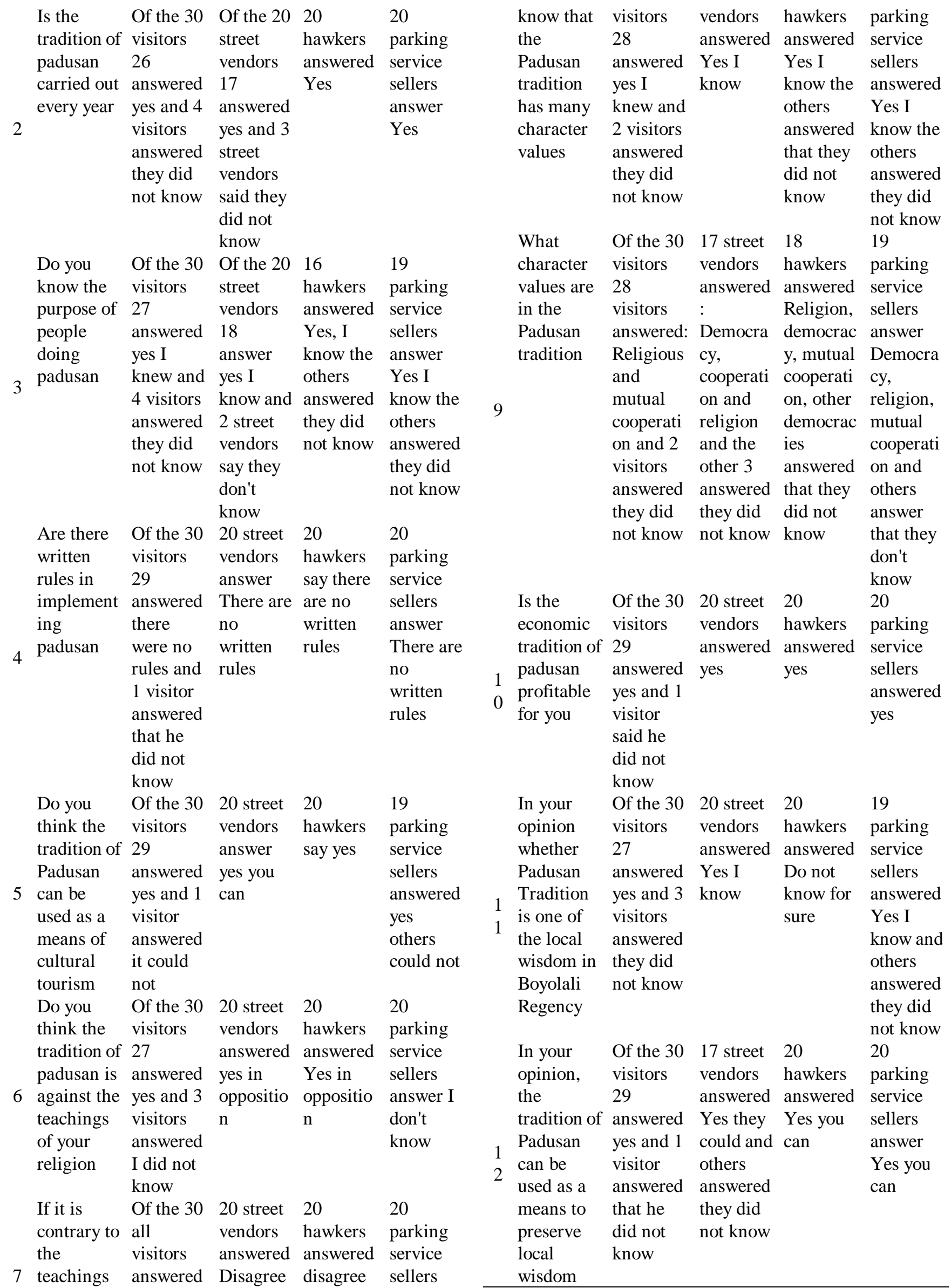
of religion, disagreea answer I it is as if it bly don't is stopped know

8 Do you Of the $30 \quad 20$ street $19 \quad 18$

Based on the results of interviews as seen in the table above, it is clear that in

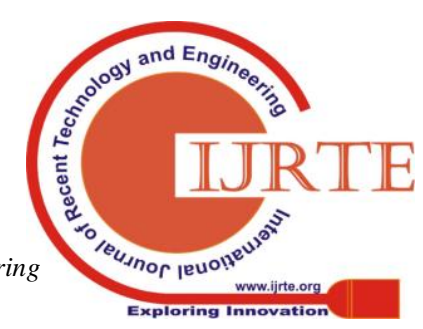


general the visitors, street vendors, hawkers, and parking attendants have knowledge of the Padusan tradition, the characters that are in the Padusan tradition. In relation to local vulnerability, the respondents also understood that the Padusan tradition was one of the local wisdoms in Boyolali District and the tradition of Padusan could be used as a means to preserve local wisdom values.

\section{B. Discussion}

Syahroni (2018) explained that the Padusan Ritual is a culture of Javanese acculturation and Islam which aims to purify oneself into the month of Ramadan the next day. Meanwhile Wawan H (2017) asserted that the Javanese community has original beliefs in the lives of its people, namely animism and dynamism. Then, the arrival of Hinduism, Buddhism and Islam encouraged the creation of more complex Javanese culture. The inclusion of the three religions into Javanese society does not necessarily eliminate the taste and form of glorification that was previously used in the beliefs of the Javanese community (http://kabartersiar.wordpress.com), thus, the acculturation between Javanese culture and the belief that is formed and the religions that came later in Java. Others with Suryani (2016) say that the cultural tradition is very much and all of them are local wisdom, meaning the ancestral heritage that must be preserved and preserved. Sujarwo (2019) although the tradition of padusan is one of local wisdom, it must be reorganized, meaning that things that are contrary to Islamic rules must be eliminated, but those that are not contradictory can still be implemented. Bunawan (2018) added that written rules must be made in the implementation of the padusan tradition so that the tradition of padusan can be used as a superior cultural tour in Boyolali Regency.

Interview with Sumitro (May 22, 2018): kulo nggih remen menawi the tradition of padusan dipun toto malih amrih saenipun. Likewise, the interview with Suminah (May 24, 2018) ingkang baken, the tradition of padusan, is still being held by uri-uri amargi, although katah sanget is beneficial. Furthermore, the interview with Reso dipuro (May 26, 2018) is very risky and has been broken by the rules even though the paddy sami's sticky soup for the courtesy of Soho is for harmony.

By basing the observations, the results of interviews with visitors, street vendors, street vendors and traditional padusan parking service sellers are something that is very unique and interesting and is an inheritance from their ancestors. The tradition of Padusan is one of the local wisdom that has religious nuances that is carried out every year and until now there are no written rules.

In terms of economics, the Padusan tradition provides a tremendous contribution to the economic value of the residents living in the vicinity of Padusan, for street vendors, hawkers and for sellers of parking services as well as the local government of Boyolali Regency. In the future the padusan tradition needs to be organized so that it does not conflict with the teachings of any religion and can instead be used as a means of preaching for a religion. Therefore, strict rules must be made as well as sanctions for visitors and those who carry out the tradition of padusan.

\section{CONCLUSION}

Based on the description of the results of the research and discussion of the results of the above research, it can be concluded: first the tradition of padusan is a hereditary culture of grandmothers who carried out once a year before the month of Ramadan. The main objective of the Padusan tradition has been to purify themselves in the face of the beginning of the month of Ramadan. Padusan tradition has many character values including: religious character values, character values.

\section{RECOMMENDATION}

Seeing the many positive sides of the Padusan tradition, the future of Padusan tradition is proposed to be one of the cultural attractions in Boyolali Regency. For this reason, improvements need to be made including the making of a written turan along with the requirements for those who do the padusan and for visitors and managers of the Padusan tradition.

\section{REFERENCE}

[1] Andina, R. E., Ridwan, A., \& Rahmawati, Y. (2019). Analisis Model Mental Siswa pada Materi Hidrolisis Garam di Klaten. JRPK: Jurnal Riset Pendidikan Kimia. https://doi.org/10.21009/jrpk.072.08

[2] Ariesto Hadi Sutopo dan Adrianus Arief, 2010. Judul : Terampil Mengolah Data Kualitatif Dengan NVIVO. Penerbit Prenada Media Group : Jakarta.

[3] Budi (2018), Tradisi Padusan di Desa Pengging, Kecamatan Banyudono Kabupaten Boyolali dikaji dari aspek ekonomis, Artikel yang dimuat dalam Jurnal pendidikan, Univet Bantara Sukoharjo Volume 27 nomor 2 tahun 2018.

[4] Bunawan (2018) Penataan Kembali pelaksanaan tradisi padusan yang bernuansa Islami, Artikel yang dimuat dalam Jurnal pendidikan, Univet Bantara Sukoharjo Volume 28 nomor 2 tahun 2018

[5] Fery (2019) dampak Ekonomis Pelaksanaan tradisi padusan di Desa Pengging, Kecamatan Banyudono Kabupaten Boyolali dikaji dari aspek ekonomis, Artikel yang dimuat dalam Jurnal pendidikan, Univet Bantara Sukoharjo Volume 27 nomor 3 tahun 2018

[6] Francis Wahono, 2005. Pangan, Kearifan Lokal dan Keanekaragaman Hayati. Yogyakarta: Penerbit Cindelaras Pustaka Rakyat Cerdas

[7] Ganug Nugroho Adi, Tradisi Jawa yang Masih Tersisa, $\mathrm{http} / / /$ kabarsoloraya.com/2010/08/14/ny (diunduh Desember 2011).

[8] Kukuh (2018) Hubungan antara Mandi prosesi mandi Padusan dengan pelaksanaan ibadah puasa bagi warga masyarakat di Kecamatan banyudono Kabupaten Boyolali Tahun 2018. Hasil Penelitian yang dimuat dalam Jurnal pendidikan, Univet Bantara Sukoharjo Volume 27 nomor 3 tahun 2018

[9] Lexy, J. Moleong. 2011. Metodologi Penelitian Kualitatif. Bandung: Remaja Rosdakarya

[10] Martadiastuti, V., Harijoko, A., Warmada, I. W., \& Yonezu, K. (2018). Hydrogeochemical Characterization of GeothermalWater in Arjuno-Welirang, East Java, Indonesia. Journal of Applied Geology. https://doi.org/10.22146/jag.39979

[11] Maryanto, S. (2017). Geo Techno Park potential at Arjuno-Welirang Volcano hosted geothermal area, Batu, East Java, Indonesia (Multi geophysical approach). AIP Conference Proceedings https://doi.org/10.1063/1.5012712

[12] Muhib al-Majdi, Risalah Ramadhan, http://arrahmah.com (diiunduh Desember 2011).

[13] Nababan, 1995. Kearifan Tradisional dan Pelestarian Lingkungan Di Indonesia. Jurnal Analisis CSIS : Kebudayaan, Kearifan Tradisional dan Pelestarian Lingkungan. Tahun XXIV No. 6 Tahun 1995

[14] Nasruddin Anshoriy dan Sudarsono, 2008. Kearifan Lingkugan, Dalam Perspektif Budaya Jawa. Yayasan Obor Indonesia

[15] Nasruddin Anshoriy dan Sudarsono, 2008. Kearifan Lingkugan, Dalam Perspektif 
Budaya Jawa. Yayasan Obor Indonesia

[16] Syahroni (2018) Keterkaitan antara tradisi padusan dengan Kearifan Lokal di Kabupaten Boyolali Tahun 2018. Artikel yang dimuat dalam Jurnal pendidikan, Univet Bantara Sukoharjo Volume 27 nomor 3 tahun 2018

[17] Suryani (2016), Mengkaji Berbagai tradisi di kabupaten Boyolali dalam konteks Kearifan Lokal, Artikel yang dimuat dalam Jurnal pendidikan, Univet Bantara Sukoharjo Volume 28 nomor 1 tahun 2018

[18] Sujarwo (2019), Revitalisasi Tradisi padusan dalam perspektif Kearifan Lokal, Artikel yang dimuat dalam Jurnal pendidikan, Univet Bantara Sukoharjo Volume 28 nomor 2 tahun 2018

[19] Sukmadinata, Nana Syaodih. 2010. Metode Penelitian Pendidikan. Bandung: Remaja Rosdakarya

[20] Suhartini. Jurnal: Kajian Kearifan Lokal Masyarakat Dalam Pengelolaan Sumberdaya Alam Dan Lingkungan. Jurusan Pedidikan Biologi FMIPA Universitas Negeri Yogyakarta

[21] Sugiyono. 2011. Metode Penelitian Kuantitatif dan Kualitatif dan R\&D. Bandung: Alfabeta, CV

[22] Sutarno. 2008. Pendidikan Multikultural. Jakarta: Direktorat Jendral Pendidikan

[23] wawan H (2017) Kepercayaan asli masyarakat jawa dalam kaitannya dengan Kearifan Lokal Artikel yang dimuat dalam Jurnal pendidikan, Univet Bantara Sukoharjo Volume 28 nomor 1 tahun 2018

[24] Widhiyastuti, R. R., Daerobi, A., \& Samudro, B. R. (2018). Community-Based Water Management: An Institutional Study In PAMDes Sumberagung, Bantul, DIY. EKO-REGIONAL JURNAL PENGEMBANGAN EKONOMI WILAYAH. https://doi.org/10.20884/1.erjpe.2017.12.2.1138

\section{AUTHORS PROFILE}

I am Suyahman, currently affiliated as a Lecturer of PPKn, FKIP Univet Bantara Sukoharjo. 